\title{
La enseñanza de la matemática. La resolución de problemas en el aula universitaria
}

\author{
Vaira, Stella ${ }^{1}$ Taborda, Liliana ${ }^{1,2}$; Manni, Diego ${ }^{1}$
}

Recibido: 26/10/2016

Aprobado: 18/11/2016

\section{Resumen}

Se ha conseguido que la enseñanza de la Matemática conecte dominios: aritmética, geometría, álgebra, análisis, caos; pero siguen siendo escasos los trabajos interactivos de la matemática con otras disciplinas. Uno de los pilares de la Educación Superior es la docencia, la enseñanza de la Matemática en contexto se presenta como fortalecedora de estrategias y aprendizaje significativo para alumnos en carreras no matemáticas.

¿Qué propone la enseñanza de la Matemática en contexto? Fortalecer el aprendizaje, sobre todo en los estudiantes universitarios que exhiben diferentes niveles de entendimiento, pero que les permitirá ir comprendiendo las ideas fundamentales asociadas con esta disciplina y los motivará hacia el estudio de otras Ciencias que conecta conceptos con ésta.

Las carreras involucradas en el trabajo son: Bioquímica, Licenciatura en Biotecnología de la Facultad de Bioquímica y Ciencias Biológicas (UNL). Este trabajo muestra los problemas, los objetivos planteados, la integración de conceptos, interpretación y los resultados obtenidos por los estudiantes universitarios.

Palabras clave: enseñanza de la matemática, resolución de problemas, contexto.

\footnotetext{
${ }^{1}$ Universidad Nacional del Litoral. Facultad de Bioquímica y Ciencias Biológicas. Ciudad Universitaria - Paraje El Pozo - CC 242 - CPA 3000ZAA -Santa Fe - Argentina. svaira@gmail.com; diegomanni@gmail.com ${ }^{2}$ Universidad Nacional de Entre Ríos. Facultad de Bioingeniería. Ruta prov. 11 km 10 Oro Verde - Paraná - Entre Ríos. taborda.Ib@gmail.com
} 
Vaira, Stella y otros | La enseñanza de la matemática. La resolución de problemas...

\section{Sumary}

It has made the teaching of Mathematics connect domains: arithmetic, geometry, algebra, analysis, chaos; but remain scarce interactive works of mathematics with other disciplines. One of the pillars of higher education is teaching, teaching of mathematics in context is presented as empowering and meaningful strategies for students not learning math careers.

What proposes the teaching of mathematics in context? Enhance learning, especially college students who exhibit different levels of understanding, but it will allow them to go understanding the fundamental ideas associated with this discipline and motivate them to study other sciences that connects concepts with it.

The races involved in the work are: Biochemistry, Bachelor of Biotechnology of the Faculty of Biochemistry and Biological Sciences (UNL). This paper shows the problems, the objectives, the integration of concepts, interpretation and results obtained by university students.

Keywords: Mathematics teaching, problem solving, context. 